\title{
Adölesan Annelerin Emzirmeye Yönelik Düşünce ve Uygulamaları
}

\author{
The Adolescent Mothers About Breastfeeding Thought and Practices
}

\author{
Sevgi ÖZSOY*
}

İletişim/Correspondence: Sevgi Özsoy Adres/Adress: Adnan Menderes Üniversitesi Aydın Sağlık Yüksekokulu Gençlik Cad. No.7 Aydın-Türkiye Tel: 0256 2138866/124 Fax: 02562124219 E-posta: sevgiozsoy09@gmail.com

\section{$\ddot{O} Z$}

Amaç: Araştırma, primipar adölesan annelerin emzirme konusundaki düşünce, tutum ve uygulamalarını belirlemek ve erişkin annelerle farklllıklarını ortaya koymak amacıyla planlandı.

Yöntem: Tanımlayıcı tipteki bu araştırmada, doğum sonu görüşülen 254 adölesan ve 223 erişkin anne yer aldl. Bilgi formu, emzirme tutum ölçeği (ETÖ) ve emzirme puanlama sistemi (LATCH) ile toplanan verilerin değerlendirilmesinde tanımlaylcr istatistikler, t testi ve ki-kare testi kullanıld.

Bulgular: Adölesan annelerin, ilk bir saat içinde emzirme, emzirme konusunda sağllk personelinden yardım alma, ETÖ ve LATCH puan ortalamalarl, erişkin annelerden anlamlı olarak düşük bulundu.

Sonuç: Adölesan anneler emzirme konusunda erişkin annelerden daha olumsuz davranıs ve tutuma sahip olup, daha fazla bilgi ve yardıma ihtiyacı vardır.

Anahtar Kelimeler: Adölesan, anne yaşl, emzirme, tutum.

\section{ABSTRACT}

Aim: This research were planned in order to identify to reveal differences about breastfeeding attitudes and practices between the primipar adolescent mothers and adult mothers.

Method: In this descriptive study has taken place 254 adolescents and 223 adults mothers. Information form, breastfeeding attitude scale and breastfeeding scoring system (LATCH) were used for data collection. Data were analyzed by descriptive statistics, $t$-test and chi-square tests.

Results: The breast-feeding within the first hour, getting help from health professionals about breastfeeding, the total score of breastfeeding attitude scale and LATCH were significantly lower the adolescent from adult mothers.

Conclusion: Adolescent mothers had a negative attitude about breastfeeding than adult mothers $n d$ are in need of more information and assistance.

Key Words: Adolescent, maternal age, breastfeeding, attitude.

*Yard. Doç. Dr. Adnan Menderes Üniversitesi Aydın Sağlık Yüksekokulu

Yazının gönderilme tarihi: 13.06.2013

Yazının basım için kabul tarihi: 23.06.2014 


\section{GíRiş}

Dünya Sağlık Örgütüne göre; 10-19 yaşları arası adölesan dönemdir ve dünyadaki her beș kişiden biri bu yaş dönemindedir. Pek çok fiziksel, psikolojik, bilişsel ve ekonomik değişimlerin yaşandığ 1 bu dönemin en önemli üreme sağlığı sorunlarından biri erken yaşta gebelik ve anne olmaktır. Dünyada her yıl çoğunluğunu gelişmekte olan ülkelerde yaşayan 15-19 yaşları arasında yaklaşık 16 milyon ve 15 yaşın altında iki milyon genç kız doğum yapmakta olup, adölesan doğumlar dünyadaki tüm doğumların \%11'ini oluşturmaktadır (WHO 2011; WHO 2012). Türkiye'de ise 15-19 yaş grubundaki kadınların \%6'sının doğurganlık davranışına başladığı ve anne olma yüzdesinin adölesan dönemde yaşla birlikte hızla arttı̆̆ bilinmektedir (Koç, Çağatay ve Adalı 2009).

Adölesan dönemde yaşanan gebeliklerde hem anne hem de bebek ölüm hızı, daha geç yaşlarda olan gebeliklere göre iki-üç kat daha yüksektir (Koç ve ark. 2009; WHO 2011; WHO 2012). Bebek ve çocuk ölümlerinin birçoğu önlenebilir nedenlerle meydana gelmektedir. Anne sütü (AS) ile beslenme, bebek ve çocuk ölümlerinin azaltılmasında önemli bir faktördür. Adölesan annelerin bebeklerinde ölüm ve hastalık riski daha yüksek olduğundan bu bebeklerin AS ile beslenmesi daha fazla önem taşımaktadır. Ancak adölesan annelerin postpartum dönemde karşılaştıkları pek çok problemin en önemlilerinden biri de laktasyonun başlatılması ve sürdürülmesidir. Araştırmalar anne yaşının emzirmenin başlatılması ve sürdürülmesinde önemli rol oynadığını, aralarında güçlü bir ilişki, olduğunu ve anne yaşı ile emzirme süresi arasında pozitif ilişki bulunduğunu göstermiştir (Akdolun Balkaya, Vural ve Eroğlu 2009; Alp 2009; Baisch, Fox, Whitten ve Pajewski 1989, Balcı ve Savaşer 1998; Dennis 2002; IşıkKoç ve Tezcan 2005; Kütük 2012; Maehr, Lizarraga, Wingard ve Felice 1993; McKechnie, Tluczek ve Henriques 2009; Santo, Oliveira, Giugliani 2007; Şahin 2011; Tatar ve Günay 2009; Thulier ve Mercer 2009; Yıldız ve Küçükşahin 2011).
Emzirme sadece fizyolojik bir olay değil öğrenilmesi gereken bir süreçtir. Bu sürecin doğumdan hemen sonra başlatılması ve sürdürülmesinde sağlık ekibine büyük görevler düşmektedir. Çünkü yenidoğanlar bakım ve beslenme konusunda tamamen ebeveynlerine özellikle de anneye muhtaçtır. Bu nedenle ilk kez anne olan kadınların bebek bakımı ve beslenmesi konusunda bilgi ve yardıma ihtiyacı vardır. Ancak anne olan kadın adölesan ise bebek bakımı ve emzirme konusunda desteklenmesi daha da önem kazanmaktadır. Kütük (2012) bu konuda yaptığı bir derlemesinde, adölesan annelerin emzirmeye yönelik sınırlı sayıda araştırma bulunduğunu, mevcut araştırma sonuçlarına göre de, adölesan annelerin emzirmeye başlama ve sürdürme performanslarının düşük olduğunu, bu performansın doğum öncesi ve sonrasında anne ve yakınları ile yapılan bilgilendirme toplantıları ile arttırılabildiğini belirtmiştir. Adölesanların emzirme konusundaki düşünce, tutum ve uygulamalarına yönelik mevcut durumun bilinmesi onlara verilecek hizmetin şekillendirilmesinde önemlidir.

$\mathrm{Bu}$ araştırma, ilk kez anne olan adölesanların emzirme konusundaki düşünce, tutum ve uygulamalarını belirlemek ve erişkin annelerle farklılıklarını ortaya koymak amacıyla planlanmıştır.

\section{YÖNTEM}

Tanımlayıcı tipteki bu araştırma, İzmir Dr. Ekrem Hayri Üstündağ Kadın Hastalıkları ve Doğum Hastanesi'nin doğum servislerinde Aralık 2009 - Şubat 2010 tarihleri arasında yapılmıştır. Araştırmanın evreninin bu tarihler arasında doğum yapan tüm adölesan ve erişkin anneler oluşturmuştur. Hastanede 2008 yılında 254'ü adölesan toplam 7722 kadın doğum yapmıştır. Evreni bilinen örnekleme yöntemi ile yapılan hesaplamaya göre belirlenen 154 adölesan anneye ulaşıncaya kadar tüm adölesan anneler araştırmaya alınmıştır. Adölesan annelerin emzirmeye yönelik düşünce, tutum ve uygulama konusundaki özelliklerini karşılaştırmak için aynı dönemde doğum yapmış toplam 1607 kadın içindeki, erişkin anneler arasından örneklem seçim kriterlerine uyan ve eğitim durumları 
adölesan annelere benzer olan 223 erişkin anne de çalışma kapsamına alınmıştır. Örneklemde primipar, sezaryen veya normal doğum yapmış, gebelik haftas 37 haftadan büyük, tek bebeği olan, bebeği yanında olan, emzirmeye engel herhangi bir durumu olmayan, araştırmaya katılmayı kabul eden, adölesan ve erişkin yaştaki anneler yer almıştır.

Verilerin toplanmasında, annelerin sosyo-demografik, obstetrik ve bebeğe ait özellikler ile emzirme konusundaki düşünce ve uygulamalarını içeren sorular yer aldığ1 "bilgi formu" ile "Emzirme Tutumunu Değerlendirme Ölçeği (ETÖ)” ve “Emzirme Puanlama Sistemi (LATCH)” kullanılmıştır.

\section{Emzirme Tutumunu Değerlendirme Ölçeği (ETÖ):} Arslan (1999) tarafından emzirme olayının çeşitli boyutları incelenerek, annelerin emzirme tutumlarını değerlendirebilmede kullanılmak üzere geliştirilmiş 46 sorudan oluşan 5'li likert tipte bir ölçektir. Ölçek içersinde yer alan 21. madde (Emzirirken diğer çocuklarımın etkileneceğini düşünürüm.) araştırma kriterine uymadığı için çıkarılmıştır. Ölçekten alınabilecek en yüksek puan 184'tür. Ancak bu araştırmada 21. madde çıkarıldığı için maksimum puan toplam 180'dir. Ölçeğin örneklem grubu için Cronbach Alpha iç tutarlılık katsayıs1 0.68 olarak bulunmuştur.

Emzirme Puanlama Sistemi (LATCH): Annelerin emzirmelerini değerlendirmek amaciyla, Jensen, Wallece ve Kelsay (1995) tarafından geliştirilen ve Demirhan (1997) tarafindan Türkçe'ye uyarlanan beş alt gruplu LATCH Puanlama Sistemi (Breastfeeding Charting System)'nin güvenirliliği, ülkemizde Koyun (2001) ile Yenal ve Okumuş (2003) tarafından yapılan çalışmalarla saptanmıştır. LATCH Puanlama Sisteminin örneklem grubumuz için uygunluğu değerlendirildiğinde Cronbach Alpha iç turarlı1ık katsayısı 0.55 olarak hesaplanmıştır.

LATCH Puanlama Sisteminde her kriter için 0, 1, 2 puan verilmektedir. Puanların toplanması ile emzirme değerlendirilmektedir. Alınabilecek maksimum puan 10 'dur. Daha düşük puan alınması annenin yar- dıma gereksinimi olduğunu gösterir. Puanlama annenin emzirmesi hemşire tarafindan gözlenerek yapılır. LATCH, emzirmeyi değerlendirmek ve gerekli durumlarda uygun girişimlerde bulunmak için beş özel kriter üzerine odaklanır. Bu kriterler;

L - (Latch); bebeğin memeyi kavramasını,

A - (Audible Swallowing); bebeğin yutkunma sesinin duyulmasinı,

$\mathrm{T}$ - (Type of Nipple); annenin meme başının tipini,

C - (Comfort of Breast/Nipple); annenin meme/meme başı rahatlı̆̆ını,

H - (Hold/Positioning); annenin bebeğini emme pozisyonuna yerleştirme için gereksinimi olan yardımı tanımlar.

Verilerin toplanmasında, her gün 08.00-16.00 saatleri arasında, araştırma kriterlerine uyan anneler belirlenmiş, Bilgi formu yüz yüze görüşme tekniği ile ETÖ ise anne tarafindan özbildirim yöntemi ile uygulanmıştır. Okuma-yazma bilmeyen annelere araştırmacı yardım etmiştir. LATCH ölçeği anne bebeğini emzirirken araştırmacı tarafindan bir kez gözlenerek doldurulmuştur. Her bir anne ile postpartum ilk üç günde görüşülmüş ve görüşme 20-30 dakika arasında sürmüş̧ür.

Verilerin değerlendirilmesi bilgisayar ortamında yapılmış, tanıtıcı özelliklerin incelenmesinde tanımlayıcı istatistikler, iki grup puan ortalamalarının karşılaştırılmasinda $t$ testi ve gruplar arasinda sosyodemografik özellikler, obstetrik özellikler ve emzirme hakkındaki düşünce ve uygulamaları bakımından fark olup olmadığının belirlenmesinde ki-kare önemlilik testi kullanılmıştır.

Araştırma için, İzmir Dr. Ekrem Hayri Üstündağ Kadın Hastalıkları ve Doğum Hastanesi Baştabipliği'nden yazılı izin ve Aydın Klinik Araştırmalar Etik kurul Başkanlığı'ndan onay alınmıştır. Araştırma kriterlerine uyan annelere araştırmanın amacı hakkında bilgi verilmiş ve araştırmaya katılmayı kabul edenlerle yazılı onamları alınarak görüşme yapılmıştır. 


\section{BULGULAR}

Adölesan annelerin yaş dağılımı 15-19 yaş arasında değişmekte olup ( 15 yaş $n=5,16$ yaş $n=15,17$ yaş $n=19,17$ yaş $n=38,19$ yaş $n=77$ ) yarısının 19 yaşında, diğerlerinin daha küçük yaşta olduğu saptanmıştır. Erişkin annelerin yaş dağılımı ise 20 ile 32 arasında olup, \%58.3'ü 23 yaş ve altında yer almaktadır. Adölesan annelerin yaş ortalaması $18.08 \pm 1.14$, erişkin annelerin ise $23.51 \pm 3.02$ 'dir. Adölesan ve erişkin annelerin eğitim durumları incelendiğinde 0 ile 11 y1l arasında eğitim aldıkları, adölesan annelerin eğitim ortalamasının 5.64 \pm 3.22 y1l, erişkin annelerin ise $6.26 \pm 3.12$ olduğu ve aralarında anlamlı fark bulunmadığı saptanmıştır ( $\mathrm{t}=1.860, \mathrm{p}>0.06)$.

Tablo 1. Adölesan ve Erişkin Annelerin Bazı Sosyo-Demografik Özellikleri.

\begin{tabular}{|c|c|c|c|c|c|c|}
\hline \multirow{2}{*}{ Değişkenler } & \multicolumn{2}{|c|}{$\begin{array}{c}\text { Adölesan } \\
\text { Anne (n=154) }\end{array}$} & \multicolumn{2}{|c|}{$\begin{array}{l}\text { Erişkin Anne } \\
\quad(n=223)\end{array}$} & \multirow{2}{*}{$\chi_{2}$} & \multirow{2}{*}{$\rho$} \\
\hline & $\mathrm{n}$ & $\%$ & $\mathrm{~N}$ & $\%$ & & \\
\hline $\begin{array}{l}\text { Aile Tipi } \\
\text { Geniş } \\
\text { Çekirdek }\end{array}$ & $\begin{array}{l}78 \\
76\end{array}$ & $\begin{array}{l}50.6 \\
49.4\end{array}$ & $\begin{array}{c}82 \\
141\end{array}$ & $\begin{array}{l}36.8 \\
63.2\end{array}$ & 7.182 & 0.005 \\
\hline $\begin{array}{l}\text { Çalışma } \\
\text { Durumu } \\
\text { Çalışıyor } \\
\text { Çalışmıyor }\end{array}$ & $\begin{array}{c}6 \\
148\end{array}$ & $\begin{array}{c}3.9 \\
96.1\end{array}$ & $\begin{array}{c}41 \\
182\end{array}$ & $\begin{array}{l}18.4 \\
81.6\end{array}$ & 17.525 & 0.000 \\
\hline $\begin{array}{l}\text { Sosyal } \\
\text { Güvence } \\
\text { Var } \\
\text { Yok }\end{array}$ & $\begin{array}{c}116 \\
38\end{array}$ & $\begin{array}{l}75.3 \\
24.7\end{array}$ & $\begin{array}{c}186 \\
37\end{array}$ & $\begin{array}{l}83.4 \\
16.6\end{array}$ & 3.735 & 0.036 \\
\hline $\begin{array}{l}\text { Gelir Düzeyi } \\
\text { Asgari ücret } \\
\text { ve altı } \\
\text { Asgari ücret } \\
\text { üstü }\end{array}$ & $\begin{array}{l}93 \\
61\end{array}$ & $\begin{array}{l}60.4 \\
39.6\end{array}$ & $\begin{array}{l}103 \\
120\end{array}$ & $\begin{array}{l}46.2 \\
53.8\end{array}$ & 7.360 & 0.004 \\
\hline
\end{tabular}

Adölesan annelerin yarısının, erişkin annelerin ise yaklaşık \%37'sinin geniş aileye sahip olduğu, adölesan annelerin neredeyse tamamı çalışmazken, erişkin annelerin \%18'inin çalıştığ ${ }^{\prime}$ saptanmıştır. Adölesan annelerin sosyal güvence ve gelir düzeyinin daha düşük oranda olduğu belirlenmiştir. Karşılaştırılan değişkenlerin hepsinde adölesan annelerle, erişkin anneler arasında istatistiksel anlamlı fark saptanmıştır (Tablo 1).
Tablo 2. Adölesan ve Erişkin Annelerin Bazı Obstetrik Özellikleri.

\begin{tabular}{|c|c|c|c|c|c|c|}
\hline \multirow{2}{*}{$\begin{array}{l}\text { Obstetrik } \\
\text { Özellikler }\end{array}$} & \multicolumn{2}{|c|}{$\begin{array}{c}\text { Adölesan } \\
\text { Anne }(n=154)\end{array}$} & \multicolumn{2}{|c|}{$\begin{array}{l}\text { Erişkin Anne } \\
\quad(n=223)\end{array}$} & \multirow{2}{*}{$\chi^{2}$} & \multirow{2}{*}{$\rho$} \\
\hline & $\mathrm{n}$ & $\%$ & $\mathrm{n}$ & $\%$ & & \\
\hline $\begin{array}{l}\text { DÖB Alma } \\
\text { Durumu* } \\
\text { Almamış } \\
\text { Almış }\end{array}$ & $\begin{array}{c}4 \\
150\end{array}$ & $\begin{array}{c}2.6 \\
97.4\end{array}$ & $\begin{array}{c}2 \\
221\end{array}$ & $\begin{array}{c}0.4 \\
99.6\end{array}$ & & \\
\hline $\begin{array}{l}\text { DÖB } \\
\text { Sirasında } \\
\text { Emzirme } \\
\text { Eğitimi } \\
\text { Alma** } \\
\text { Evet } \\
\text { Hayır }\end{array}$ & $\begin{array}{c}26 \\
128\end{array}$ & $\begin{array}{l}16.9 \\
83.1\end{array}$ & $\begin{array}{c}71 \\
152\end{array}$ & $\begin{array}{l}31.8 \\
68.2\end{array}$ & 10.662 & 0.001 \\
\hline $\begin{array}{l}\text { Doğum } \\
\text { Şekli } \\
\text { Normal } \\
\text { Sezaryen }\end{array}$ & $\begin{array}{l}85 \\
69\end{array}$ & $\begin{array}{l}55.2 \\
44.8\end{array}$ & $\begin{array}{l}108 \\
115\end{array}$ & $\begin{array}{l}48.4 \\
51.6\end{array}$ & 1.668 & 0.197 \\
\hline $\begin{array}{l}\text { Bebeğin } \\
\text { Cinsiyeti } \\
\text { K1z } \\
\text { Erkek }\end{array}$ & $\begin{array}{l}84 \\
70\end{array}$ & $\begin{array}{l}54.5 \\
45.5\end{array}$ & $\begin{array}{l}103 \\
120\end{array}$ & $\begin{array}{l}46.2 \\
53.8\end{array}$ & 2.545 & 0.068 \\
\hline $\begin{array}{l}\text { Gebeliği } \\
\text { İsteme } \\
\text { Durumu } \\
\text { İstedi } \\
\text { Daha sonra } \\
\text { istedi/Hiç } \\
\text { istemedi }\end{array}$ & $\begin{array}{c}110 \\
44\end{array}$ & $\begin{array}{l}71.4 \\
28.6\end{array}$ & $\begin{array}{c}184 \\
39\end{array}$ & $\begin{array}{l}82.5 \\
27.5\end{array}$ & 6.517 & 0.008 \\
\hline
\end{tabular}

* Sayılar küçük olduğu için ki kare yapılmamıştır.

** Sadece DÖB alanlar analiz edilmiştir.

Adölesan ve erişkin annelerin bazı obstetrik özellikleri karşılaştırıldığında, hem adölesan hem de erişkin annelerin tamamına yakını DÖB aldığını ifade etmiştir. Ancak DÖB sırasında emzirme eğitimi aldığını belirten anne oranı çok azdır ve bu oran adölesan annelerde daha az olup erişkin annelerle aralarında ileri derecede anlamlı fark saptanmıştır. Adölesan annelerin doğum şekli erişkin annelerden fak11 olmayıp hem adölesan hem de erişkin anneler arasında sezaryen olma oranının oldukça yüksek olduğu belirlenmiştir. Adölesan ve erişkin anneler arasında bebeğin cinsiyeti bakımından bir fark bulunmamıştır. Ancak adölesan annelerin yaklaşık \%29'u gebeliğini istemediğini ifade etmiş ve gebeliğgi isteme durumu erişkin annelerden istatistiksel olarak farklı bulunmuştur (Tablo 2). 
Tablo 3. Adölesan ve Erişkin Annelerin Emzirmeye İlişkin Bilgi ve Uygulamaları.

\begin{tabular}{|c|c|c|c|c|c|c|}
\hline \multirow{2}{*}{$\begin{array}{l}\text { Emzirmeye İlişkin Bilgi ve } \\
\text { Uygulamalar }\end{array}$} & \multicolumn{2}{|c|}{ Adölesan Anne $(n=154)$} & \multicolumn{2}{|c|}{ Erişkin Anne (n=223) } & \multirow[b]{2}{*}{$\chi_{2}$} & \multirow[b]{2}{*}{$\rho$} \\
\hline & $\mathbf{n}$ & $\%$ & n & $\%$ & & \\
\hline $\begin{array}{l}\text { Sadece AS Verme Süresi } \\
6 \text { ay } \\
\text { Bilmiyor/yanlış biliyor }\end{array}$ & $\begin{array}{c}104 \\
50\end{array}$ & $\begin{array}{l}67.5 \\
32.5\end{array}$ & $\begin{array}{c}162 \\
61\end{array}$ & $\begin{array}{l}72.6 \\
27.4\end{array}$ & 1.146 & 0.302 \\
\hline $\begin{array}{l}\text { Toplam Emzirilme Süresi } \\
24 \text { ay } \\
\text { Bilmiyor/yanlış biliyor }\end{array}$ & $\begin{array}{c}35 \\
119\end{array}$ & $\begin{array}{l}22.7 \\
77.3\end{array}$ & $\begin{array}{c}64 \\
159\end{array}$ & $\begin{array}{l}28.7 \\
71.3\end{array}$ & 1.678 & 0.119 \\
\hline $\begin{array}{l}\text { İlk Emzirme Zamanı } \\
\text { İlk bir saat içinde } \\
\text { Bir saatten geç }\end{array}$ & $\begin{array}{l}68 \\
86\end{array}$ & $\begin{array}{l}44.2 \\
55.8\end{array}$ & $\begin{array}{c}125 \\
98\end{array}$ & $\begin{array}{l}56.0 \\
44.0\end{array}$ & 5.161 & 0.028 \\
\hline $\begin{array}{l}\text { AS Dışında Sıvı ya da Besin V } \\
\text { Durumu } \\
\text { Verildi } \\
\text { Verilmedi }\end{array}$ & $\begin{array}{c}50 \\
104\end{array}$ & $\begin{array}{l}32.5 \\
67.5\end{array}$ & $\begin{array}{c}69 \\
154\end{array}$ & $\begin{array}{l}31.0 \\
69.0\end{array}$ & 0.098 & 0.822 \\
\hline $\begin{array}{l}\text { Emzirme ya da Meme Sorunu } \\
\text { Yaşama Durumu } \\
\text { Evet } \\
\text { Hayır }\end{array}$ & $\begin{array}{l}80 \\
74\end{array}$ & $\begin{array}{l}51.9 \\
48.1\end{array}$ & $\begin{array}{c}98 \\
125\end{array}$ & $\begin{array}{l}44.0 \\
56.0\end{array}$ & 2.340 & 0.142 \\
\hline $\begin{array}{l}\text { Hastanede Sağlık Personelinin } \\
\text { Emzirme Desteği } \\
\text { Oldu } \\
\text { Olmadı }\end{array}$ & $\begin{array}{c}41 \\
113\end{array}$ & $\begin{array}{l}26.6 \\
73.4\end{array}$ & $\begin{array}{c}96 \\
127\end{array}$ & $\begin{array}{l}43.0 \\
57.0\end{array}$ & 10.624 & 0.001 \\
\hline
\end{tabular}

Adölesan ve erişkin anneler arasında bebeğin sadece anne sütü (SAS) alması gereken süreyi ve toplam emzirilme süresini doğru bilme ile bebeğe AS dışında başka bir besin verme ve emzirme ya da meme sorunu yaşama durumu bakımından anlamlı farklılık saptanmamıştır. Doğumdan sonra bir saat içinde emzirmeye başlama ile emzirme için sağlık personelinden yardım alma, adölesan annelerde daha az oranda olup erişkin annelerle aradaki fark istatistiksel olarak anlamlı bulunmuştur (Tablo 3).

Tablo 4. Adölesan ve Erişkin Annelerin ETÖ VE LATCH Toplam Puan Ortalamaları Arasındaki İlişki.

\begin{tabular}{|c|c|c|c|c|c|c|}
\hline & $\begin{array}{l}\text { Anne } \\
\text { Tipi }\end{array}$ & $\mathrm{n}$ & $\bar{x}_{1}$ & SS & $\mathrm{t}$ & $\rho$ \\
\hline \multirow{2}{*}{$: 0$} & $\begin{array}{l}\text { Adölesan } \\
\text { anne }\end{array}$ & 154 & 99.292 & 13.381 & \multirow[t]{2}{*}{1.202} & \multirow[t]{2}{*}{0.000} \\
\hline & $\begin{array}{l}\text { Erişkin } \\
\text { anne }\end{array}$ & 223 & 110.713 & 13.920 & & \\
\hline \multirow{2}{*}{ 己 } & $\begin{array}{c}\text { Adölesan } \\
\text { anne }\end{array}$ & 154 & 6.487 & 1.794 & \multirow[t]{2}{*}{12.050} & \multirow[t]{2}{*}{0.000} \\
\hline & $\begin{array}{l}\text { Erişkin } \\
\text { anne }\end{array}$ & 223 & 8.0314 & 1.505 & & \\
\hline
\end{tabular}

Adölesan annelerin ETÖ'den aldıkları puanlar 65 ile 136, erişkin annelerin ise 81 ile 149 arasında değiştiği, erişkin annelerin ETÖ toplam puan ortalamasının adölesan annelerden yaklaşık 11 puan daha yüksek olduğu ve aradaki farkın ileri düzeyde anlamlılık gösterdiği saptanmıştır (Tablo 4).

Annelerin emzirmesi LATCH'a göre gözlenip değerlendirildiğinde, adölesan annelerin puanı 1 ile 10, erişkin annelerin puanı ise 4-10 arasında dağılım göstermiştir. LATCH toplam puanı ortalamaları karşılaştırıldığında ise adölesan annelerin ortalamasının, erişkin annelerinkinden yaklaşık 1.5 puan daha az olduğu ve bu farkın ileri derecede anlamlı olduğu belirlenmiştir.

Adölesan ve erişkin annelerin ETÖ ve LATCH toplam puan ortalamaları arasındaki anlamlı faklılığın, annelerin sosyo-demografik özellikleri arasındaki farklılıktan kaynaklanmış olabileceği düşünülmüştür. Anneler sosyo-demografik özellikler açısından eşleştirildiğinde de (adölesan=154, erişkin=199) ETÖ (adölesan 99.292 \pm 13.381 , erişkin $110.070 \pm 13.623, \mathrm{t}=7.429$, $\mathrm{p}<0.000$ ) ve LATCH (adölesan 6.487 \pm 1.794 ,.erişkin 
$7.974 \pm 1.528, \mathrm{t}=8.403, \mathrm{p}<0.000)$ toplam puan ortalamaları arasındaki farklılık değişmemiştir.

\section{TARTIŞMA}

Primipar adölesan annelerin emzirme konusundaki düşünce, tutum ve uygulamalarını belirlemek ve erişkin annelerden olan farklılıklarını ortaya koymak amacıyla planlanan bu çalışmada adölesan annelerin emzirme konusundaki düşünce ve uygulamalarının erişkin annelerden daha olumsuz olduğu saptanmıştır. Literatürde kadınların emzirmeye ilişkin bilgi ve uygulamalarına yönelik araştırmalar olmasına karşın, özel olarak adölesanlarla yapılmış araştırmalar olmadığından bu araştırmanın bulguları, daha çok kendi içinde ve adölesanların erişkinlerle olan farkları üzerinde tartıŞılmıştır.

Araştırmanın yürütüldüğü tarihlerde hastanede doğum yapan tüm kadınların yaklaşı \%10'unu adölesanlar oluşturmuştur. TNSA-2008 araştırması sonuçlarına göre Ege Bölgesindeki adölesan doğurganlık oran1 \%9.3, olup Doğu Anadolu Bölgesinden sonra en yüksek adölesan doğurganlık oranına sahip ikinci bölgedir (Koç ve ark. 2009). Araştırmada yer alan adölesan annelerin yaklaşı \% \%6'sının en uzun süre yaşadığ1 yer de Ege Bölgesidir. TNSA-2008 araştırmasından yaklaşık 2 yıl sonra yürütülen araştırmamızdaki adölesan doğurganlık oranının TNSA-2008 sonuçlarından biraz yüksek olduğu ve Ege Bölgesinin hala yüksek adölesan doğurganlık oranını koruduğu söylenebilir. Yine TNSA 2008 de belirtildiği gibi (Koç ve ark. 2009) araştırmamızda da yaş arttıkça adölesanlar arasında anne olma oranının arttığı saptanmıştır (Tablo 1).

Adölesan annelerin emzirmeye yönelik tutum ve davranışlarının, erişkin annelerden farkını belirlemek için araştırmada yer alan benzer özelliklere sahip erişkin annelerin yarısından fazlası yirmili yaşların başlarında yer almaktadır. Adölesan annelerle erişkin anneler arasında eğitim durumu açısından istatistiksel farkl11.k saptanmamıştır. Bu durum örneklem seçiminde erişkin annelerin adölesan annelere benzer özel- liklere sahip annelerin seçilmesinden kaynaklanmıştır. Ancak anneler sosyo-demografik özellikler açısından karşılaştırıldığında adölesan annelerin erişkin annelere göre istatistiksel olarak anlamlı düzeyde, daha fazla oranda geniş ailede yaşadıkları, sosyal güvenceden yoksun oldukları, gelir durumlarının düşük seviyede olduğu ve daha az oranda çalıştıkları saptanmıştır (Tablo 1).

Hem adölesan hem de erişkin annelerin tamamına yakınının DÖB aldığı sadece adölesan annelerden dördünün, erişkin annelerden ise ikisinin almadığı saptanmıştır (Tablo 2). DÖB almayan dört adölesan annenin, üçünün sosyal güvencesinin olmaması birinin ise yeşil kartlı olduğu belirlenmiştir. Bilindiği gibi yoksulluk, anne ve bebek morbidite ve mortalitesini arttırmaktadir. Hem adölesan hem düşük eğitim düzeyi hem de yoksul olan anne ve bebekleri, birden fazla risk faktörüne sahiptir. Bu nedenle DÖB almaları az sayıda da olsa bu kadınlar için daha da önem taşırken bu hizmetten yararlanmadıkları görülmüştür. DÖB'ın sorgulandığ 1 birçok araştırmada da adölesan annelerin, erişkin annelerden daha az oranda DÖB aldığı belirlenmiştir (Çetin, Güneş, Karaoğlu ve Üstün 2005; Demirgöz ve Canbulat 2008; Kütük 2012; Şekeroğlu ve ark. 2009). Şahin (2011) araştırmasında yer alan 163 adölesan'ın yarısından fazlasının (\%51.5), TNSA 2008 sonuçlarına göre de ülkemizde adölesanların \%8'inin, Ege Bölgesinde ise \%3.1'inin DÖB almadığı belirlemiştir (Akadlı Ergöçmen, Tezcan ve Çağatay 2009). Araştırma sonuçlarımız Ege Bölgesi ortalamasına benzerdir.

Dünya Sağlık Örgütü ve Sağlık Bakanlığı DÖB sırasında gebelere emzirme eğitiminin verilmesini önermektedir. Bebeğin AS ile beslenmesini sağlamak, özendirmek ve desteklemenin amaçlandığ 1 "Başarılı Emzirmede 10 Adım” ilkelerinin üçüncü ilkesi antenatal izlemler sırasında "tüm hamile kadınları emzirmenin yararları ve uygulaması hakkında bilgilendirmek" dir. Bu açıdan adölesan annelerin DÖB sırasında emzirme konusunda bilgilendirilme durumu incelendiğinde, hem adölesan hem de erişkin annelerin büyük çoğunluğunun bu konuda bilgi almadığı belirlenmiştir 
(Tablo 2). Araştırmada yer alan adölesan annelerin büyük çoğunluğu DÖB aldığını belirtmesine karşın, bu bakımın içeriğinde emzirme eğitiminin yer almaması, adölesan gebeliklerin DÖB veren sağlık çalışanlarınca yeterince önemsenmediğini düşündürmektedir. Bilgi aldığını belirten anneler arasında adölesanların ora$\mathrm{n}$ erişkin annelerin yaklaşık yarısıdır ve aradaki fark ileri derecede anlamlıdır. Bu durum riskli gebe grubunda yer alan ve daha fazla önem gösterilmesi gereken adölesan annelerin nitelikli bir DÖB alamadıklarını göstermektedir. Başka araştırmalarda da adölesan olsun olmasin gebelere DÖB sirasında emzirme bilgisinin yeterince verilmediğini göstermektedir (Çetin ve ark. 2005; Gölbaşı ve Koç 2008; Işık Koç ve Tezcan 2005). Bu durum sağlık personelinin adölesan gebeliklere yaklaşımı konusunda araştırmalar yapılması gerektiğini göstermektedir.

TNSA 2008 sonuçlarına göre 20 yaş altındaki kadınların \%20'si gebeliği istemediğini belirtmiştir (Eryurt, Türkyılmaz ve Çağatay 2009). Bu araştırmada yer alan adölesanların gebeliği istememe oranı (\%29) hem Türkiye ortalamasından hem de araştırma grubumuzdaki erişkin annelerden anlamlı olarak daha yüksektir (Tablo 2). Bu durum adölesanların henüz anne olmaya hazır olmadıklarının kendilerinin de farkında olduğunu ve doğurganlığın düzenlenmesi konusunda danışmanlığa ihtiyaçları olduğunu göstermektedir.

DSÖ ve Sağlık Bakanlığı bebekler için ideal beslenme biçimini, ilk altı ay SAS, daha sonra uygun ek besinlerle iki yaşına kadar emzirilmenin sürdürülmesi olarak önermektedir. DÖB sırasında da bu bilginin annelere verilmesi ve bebeklerin doğar doğmaz en geç ilk bir saat içinde emzirilmenin başlatılması gerekmektedir. Adölesan annelerin emzirmeye yönelik düşünce ve uygulamaları irdelendiğinde (Tablo 3 ) bebeğine SAS vermesi gereken süreyi ve bebeğin toplam emzirilme süresini doğru bilme oranı ile doğumdan sonra bebeğini ilk bir saat içinde emzirmeye başlama durumunun, erişkin annelerden daha düşük oranda olduğu belirlenmiştir, ancak bu farklılıklar anlamlı bulunmamıştır. TNSA-2008'e göre Ege Bölgesi'nde annele- rin \%41.7'si doğumdan sonraki ilk bir saat içinde emzirmeye başlamıştır (Yiğit Kurtuluş, Tezcan ve Tunçkanat 2009). Bu açıdan karşılaştırıldığında hem adölesan hem de erişkin annelerin Ege Bölgesi yüzdesinden daha yüksek oranda erken emzirmeye başladığı söylenebilir. İstatistiksel olarak anlamlı olmasa da bebeğe AS dişında başka bir besin verme ve emzirme ya da meme sorunu yaşama oranı da adölesan annelerde daha yüksek orandadır. TNSA 2008 de anne sütünden önce başka bir gıda alanların yüzdesi 25.8' dir (Yiğit Kurtuluş ve ark. 2009). Buna göre bu araştırma da yer alan bebeklerde, hayatlarının ilk günlerinde AS dışında başka bir gıda alma oranı daha yüksektir.

Adölesan dönemde yaşanan gebeliğin annede emzirme tutum ve davranışını nasıl etkilediği belirlemek için kullanılan ETÖ irdelendiğinde (Tablo 4), adölesan annelerin (yaklaşık 99), erişkin annelerden (yaklaşık 111) daha düşük puan aldığı ve aralarındaki 11 puandan fazla farkın istatistiksel olarak ileri derecede anlamlı olduğu saptanmıştır. Bilindiği gibi ölçekten alınabilecek maksimum puan 180 olup, ETÖ'den alınan puanın yüksek olması annenin emzirme tutumunun iyi olduğunu göstermektedir. Ölçek ortalamasının 90 olduğu dikkate alınırsa adölesan annelerin ortalamanın biraz üstünde puan aldıkları bu nedenle emzirmeye yönelik tutumlarının orta düzeyde ancak kendilerinden sadece yaklaşık beş yaş büyük olan erişkin annelere göre daha kötü olduğu söylenebilir. Bu durum DÖB'ın bir parçası olan emzirme eğitiminin hem adölesan hem de erişkin annelere yeterince verilmemiş olmasından kaynaklanmış, erişkin annelerin sadece \%30'unun, adölesan annelerin \%17'sinin DÖB s1rasında emzirme eğitimi alması ETÖ puanlarını etkilemiş olabilir. Ayrıca erişkin dönemdeki sağlığı etkileyecek pek çok alışkanlık, davranış ve tutum adölesan dönemde kazanılır. Henüz fiziksel, sosyal ve psikolojik gelişimini tamamlamış bir kız çocuğunda kendinin ve çocuklarının sağlığını etkileyecek bazı davranışlar henüz kazanılmamış olabilir hele planlanmamış bir gebelik özellikle emzirme konusunda olumsuz tutum geliştirmelerine yol açmış olabilir. Işık Koç ve Tezcan (2005) gebelerle yürüttükleri çalışmaların- 
da 19 yaş ve altındaki 6 gebenin ETÖ'den ortalama 99 puan aldığını ve araştırmada yer alan tüm kadınlarda yaş arttıkça alınan puanın da arttığını saptamıştır. Bu bakımdan sonuçlar, Işık Koç ve Tezcan (2005)'in çalışması ile uyumluluk göstermektedir. Trabzon'da 405 anneyle yürütülen ve 21 yaş altındaki anne oran1nın \%11 olduğu bir çalışmada, anne yaşı ile ETÖ puan ortalamaları arasında anlamlı bir fark saptanmamıştır (Yiğitbaş, Kahriman, Yeşilçiçek Çalık ve Kobya Bulut 2012). Mossman ve ark. (2008) 103 adölesan anne ile yürüttükleri bir çalışmada doğum öncesi emzirme tutumu ve emzirme özyeterlilik puanları yüksek olan adölesanların, doğum sonrasında da puanlarının yüksek olduğunu ve emzirme oranlarının daha yüksek olduğunu belirtmişlerdir. Bu durum emzirme konusunda olumsuz düşünce ve tutuma sahip olan adölesanların gebelikte belirlenip, düşünce ve tutumlarının değişmesi için eğitilebileceğini düşündürmektedir.

Emzirme gözlenerek puanlanan LATCH'a göre annelerin aldıkları puanların dağılımı irdelendiğinde, adölesan anneler en düşük olarak, bir puan alırken, adölesan anneler gibi ilk kez anne olan erişkin annelerde en düşük puan, dört olmuştur (Tablo 5). Adölesan anneler LATCH'dan toplam on puan üzerinden ortalama 6.5 puan almıştır. Bu puan erişkin annelerin ortalama puanından yaklaşık bir buçuk puan daha düşüktür ve aradaki fark istatistiksel olarak çok ileri düzeyde anlamlı bulunmuş̧tur. Bebek dostu olan ve olmayan bir hastanede doğum yapan annelerle yapılan bir çalışmada, anne yaşının LATCH puanını etkilediğini belirlenmiştir (Çelebioğlu, Tezel ve Özkan 2006). Adölesan ve erişkin anneler sosyo-demografik özellikler açısından eşleştirildiğinde de hem ETÖ hem de LATCH toplam puan ortalamaları arasındaki faklılı̆̆ın değişmemesi, sadece yaş faktörünün annenin becerisine etkisini açıkça göstermektedir. Santo, Oliveira ve Giugliani (2007) annelerin bebeklerine erken ek gıdaya başlamasını (altı aydan önce) dört faktörün etkilediğini belirlemişlerdir. Bunlar annenin 20 yaşından küçük olmas1, altıdan az DÖB alması, bebeğin ilk bir ayda emzik kullanmaya başlaması ve LATCH'a benzer kriterlerle yapılan bir gözlemden olumsuz olarak değerlen- dirilmesidir. McKehnie, Tluczek ve Henriques (2009) de araştırmalarında anne yaşının SAS verme süresini etkilediğini belirlemişlerdir. Maehr ve ark. (1993) doğum sonu ilk iki gün içinde annelerin emzirme konusundaki kararlarını araştırdıkları çalışmalarında, adölesanların erişkinlerden emzirme konusunda farklı düşündüklerini, bu sonucun gebelik öncesi, gebelik ve gebelik sonrası dönemde de farklı olduğunu saptamışlardır. Wambach ve ark. (2000) Adölesanlar ve Emzirme isimli derlemesinde, adölesanların etraflarında emziren kadın görme olasılıklarının yetişkinlerden daha az olduğunu ve bu durumun emzirme konusundaki karar, davranış ve emzirme süresini etkilediğini, ayrıca hem adölesanlar hem de yetişkinlerde kendilerinin emzirilmiş olmasının bebeklerini de emzirme olasılıklarını arttırdığını belirtmişlerdir.

\section{SONUÇ VE ÖNERİLER}

Sonuç olarak adölesan annelere DÖB'da daha az emzirme bilgisi verildiği, gebeliklerini istemedikleri, doğumdan sonra bebeklerini daha geç emzirdikleri, hastanede emzirme için sağlık personelinden daha az destek aldıkları ve hem ETÖ hem de LATCH puanlarının erişkin annelerden daha düşük olduğu saptanmıştır. Annelerinin adölesan olmasına bağlı karşılaştıkları riskler göz önüne alındığında, bebekleri için emzirmenin hayati önem taşıdığını, doğum öncesi bakım veren hemşireler ve diğer sağlık personeli dikkate almalıdır. $\mathrm{Bu}$ nedenle kadın sağlığı hemşireleri ve diğer sağlık personeli, emzirmeye yönelik tutumlarının iyileştirilmesi ve geliştirilmesi için doğum öncesi ve sonrası onlara daha fazla zaman ayırmalı, emzirme eğitimi vermeli, her izlemde emzirme konusundaki düşünceleri hakkında konuşmalı, doğum sonu dönemde emzirmeyi öğretmeli ve davranışlarını desteklemelidir. Bu yaklaşım adölesan annenin annelik duygusuna, emzirmeyi becerebilme özgüveninin ve bebeğine daha iyi bakım verebilme yetisinin gelişmesine ve bu yolla bebeklerinin sağlığına katkı sağlayabilir.

Ege Bölgesi gibi adölesan doğurganlığın yüksek olduğu bölgelerdeki hastaneler, adölesan poliklinikleri oluşturabilir. Adölesan gebelik ve annelik konusun- 
da eğitilmiş hemşirelerle, adölesanların doğum öncesi ve sonras1 emzirme, gebelikten korunma gibi önemli konularda eğitilmeleri, doğum öncesi bu fırsatı kaçırmış adölesan annelerin ise bu eğitimi hemşireden almadan, hastaneden taburcu edilmemeleri planlanabilir. Böylece hem adölesan anne hem de bebeğinin pek çok riskten korunması sağlanabilir.

\section{TEŞEKKÜR}

$\mathrm{Bu}$ araştırmanın verilerinin toplanmasındaki katkılarından dolayı meslektaşım Gaye Güvendiren Aydın'a ve desteğinden dolayı Adnan Menderes Üniversitesi Bilimsel Araştırma Projeleri'ne teşekkür ederim.

\section{KAYNAKLAR}

Akadlı Ergöçmen, B., Tezcan, S., Çağatay, P. (2009). Üreme Sağlığg, Türkiye Nüfus ve Sağllk Araştırmasl, 2008 (TNSA 2008). Hacettepe Üniversitesi Nüfus Etütleri Enstitüsü, Sağlık Bakanlığı Ana Çocuk Sağlığı ve Aile Planlaması, Genel Müdürlüğü, Başbakanlık Devlet Planlama Teşkilatı Müsteşarlığı ve TÜBİTAK, Ankara.

Akdolun Balkaya, N., Vural, G., Eroğlu, K. (2009). Factors affecting exclusive breastfeeding in the first six weeks postpartum in Bolu, Turkey. Turkiye Klinikleri J Gynecol Obst., 19(3): 142-149.

Alp, H. (2009). Çocuklarda anne sütü ile beslenme süresi ve ilişkili faktörler. Güncel Pediatri, 7: 45-52.

Arslan, H. (1999). Emzirme tutumunu değerlendirme ölçeği geliştirme. Hemşirelik Forumu, 2(3): 132-136.

Baisch, M. J., Fox, F., Whitten, E., Pajewski, N. (1989). Comparison of breastfeeding attitudes and practices: Low-income adolescents and adult women. Maternal-Child Nursing Journal, 18(1): 61-71.

Balcı, S., Savaşer, S. (1998). Annelerin bebeklerini algılama durumu. Uluslararası Katılımlı VI. Ulusal Hemşirelik Kongre Kitabl, Ankara, 215-221.

Çelebioğlu, A., Tezel, A., Özkan, H. (2006). Bebek dostu olan ve olmayan hastanelerde emzirme durumunun karşılaştırılması. Atatürk Üniversitesi Hemşirelik Yüksekokulu Dergisi, 9(3): 44-51.

Çetin, F., Güneş, G., Karaoğlu, L., Üstün, Y. (2005). Turgut Özal Tıp Merkezi'nde doğum yapan annelerin doğum öncesi bakım alma ve emzirmeye başlama durumları ve etkileyen faktörler. İn̈nü Üniversitesi Tıp Fakültesi Dergisi, 12(4): 247-252.

Demirgöz, M., Canbulat, N. (2008). Adölesan gebelik. Türkiye Klinikleri J Med Sci, 28(6): 947-952.
Demirhan, F. (1997). Sakarya ilinde emzirmenin değerlendirilmesi. Yüksek Lisans Tezi, Marmara Üniversitesi Sağlık Bilimleri Enstitiüsü, İstanbul.

Dennis, C. L. (2002). Breastfeeding initiation and duration: A 1990-2000 literature review. JOGNN, 31(1): 12-32.

Eryurt, M. E., Türkyılmaz, A. S., Çağatay, P. (2009) Doğurganlık tercihleri, Türkiye Nüfus ve Sağlık Araştırması, 2008 (TNSA 2008). Hacettepe Üniversitesi Nüfus Etütleri Enstitüsü, Sağlık Bakanlığı Ana Çocuk Sağlığı ve Aile Planlaması, Genel Müdürlügüu, Başbakanlık Devlet Planlama Teşkilatı Müsteşarlığı ve TÜBİTAK, Ankara.

Gölbaşı, Z., Koç, G. (2008). Kadınların postpartum ilk 6 aylık süredeki emzirme davranışları ve prenatal dönemdeki emzirme tutumunun emzirme davranışları üzerindeki etkisi. Sağllk Bilimleri Fakültesi Hemşirelik Dergisi, 15(1): 16-31.

Işık Koç, G., Tezcan, S. (2005). Gebelerin emzirmeye ilişkin tutumları ve emzirme tutumunu etkileyen bazı faktörler. Hacettepe Üniversitesi Hemşirelik Yüksekokulu Dergisi, 1-13.

Jensen, D., Wallece, S., Kelsay, P. (1995). LATCH: A breastfeeding charting system and documentation tool. J. Obstet Gynecol Neonatal Nursing, 23(1): 13.

Koç, İ., Çağatay, P., Adalı, T. (2009). Doğurganlık, Türkiye Nüfus ve Sağlık Araştırması, 2008 (TNSA 2008). Hacettepe Üniversitesi Nüfus Etütleri Enstitüsü, Sağlık Bakanlığı Ana Çocuk Sağlığı ve Aile Planlaması, Genel Müdürlüğü, Başbakanlık Devlet Planlama Teşkilatı Müsteşarlığı ve TÜBİTAK, Ankara.

Koyun, K. (2001). Latch tanılama ölçeğinin kullanımı ve yenidoğan emzirme başarısını inceleyen bir çalışma. Yüksek Lisans Tezi, Dokuz Eylül Üniversitesi Sağlık Bilimleri Enstitüsü, İzmir.

Kütük, S. (2012). Adölesan gebelik riskleri ve sorunları. Türk Aile Hek Derg, 16: 31-34.

Maehr, J. C., Lizarraga, J. L., Wingard, D. L., Felice, M. E. (1993). A comparative study of adolescent and adult mothers who intend to breastfeed. J Adolesc Health, 14(6): 453-457.

McKechnie, A. C., Tluczek, A., Henriques, J. B. (2009). Maternal variables influencing duration of breastfeeding among low-income mothers. ICAN: Infant, Child \& Adolescent Nutrition, 1(3): 125132

Mossman, M., Heaman, M., Dennis, C. L., Morris, M. (2008). The Influence of adolescent mothers' breastfeeding confidence and attitudes on breastfeeding initiation and duration. J Hum Lact., 24(3): 268-277.

Santo, A. C. E., Oliveira, L. D., Giugliani, E. R. J. (2007). Factors associated with low incidence of exclusive breastfeeding for the first 6 months. BIRTH, 34(3): 212-219. 
Şahin, M. (2011). Gebelik yaşının anne ve yenidoğan sağlığına etkilerinin değerlendirilmesi. Yüksek Lisans Tezi, Mersin Üniversitesi Sağlık Bilimleri Enstitüsü, Mersin.

Şekeroğlu, M. ve ark. (2009). Adölesan ve ileri yaş gebeliklerde obstetrik sonuçlar. Şişli Etfal Hastanesi Tıp Bülteni, 43(1): 1-7.

Tatar, M. G., Günay, O. (2009). Kahramanmaraş il merkezindeki gebelerin emzirme konusundaki bilgi ve tutumları. Sağllk Bilimleri Dergisi, 18(3): 175-186.

Thulier, D., Mercer, J. (2009). Variables associated with breastfeeding duration. JOGNN, 38: 259-268.

Wambach, K. A., Cole, C. (2000). Breasqeeding and adolescents. JOGNN, 29(3): 282-294.

World Health Organization (WHO) (2011). Young people: Health risks and solutions, Agust, http://www.who.int/mediacentre/factsheets/fs345/en/index.html (30.04.2013)

World Health Organization (WHO) (2012). Adolescent Pregnancy. Issues in Adolescent Health and Development. Department of Child and Adolescent Health and Development, WHO, Geneva, http://www.who.int/mediacentre/factsheets/fs364/en/ (30.04.2013)

Yenal, K., Okumuş, H. (2003). LATCH emzirme tanılama aracının güvenilirliğini inceleyen bir çalışma. Hemşirelikte Araştırma Geliştirme Dergisi, 5(1): 38-44.

Yıldız, H., Küçükşahin, N. (2011). Kırsal bölgede annelerin doğum sonu yaşadıkları sorunlar ve bakım gereksinimleri. Türk Aile Hek Derg, 15(4): 159-166.

Yiğitbaş, Ç., Kahriman, İ., Yeşilçiçek Çalık, K., Kobya Bulut, H. (2012). Trabzon il merkezindeki hastanelerde doğum yapan annelerin emzirme tutumlarının değerlendirilmesi. Gümüşhane Üniversitesi Sağlık Bilimleri Dergisi, 1(2): 49-59.

Yiğit Kurtuluş, E., Tezcan, S., Tunçkanat, H. (2009). Çocukların ve Annelerin Beslenme Durumu, Türkiye Nüfus ve Sağlık Araştırması, 2008 (TNSA 2008). Hacettepe Üniversitesi Nüfus Etütleri Enstitüsü, Sağlık Bakanlığı Ana Çocuk Sağlı̆̆ı ve Aile Planlaması, Genel Müdürlüğü, Başbakanlık Devlet Planlama Teşkilatı Müsteşarlığı ve TÜBİTAK, Ankara. 